\title{
1. Introduction: expanding spheres of public-private cooperation
}

This book is written for students of international law, international development, governance, public policy, finance, innovative business and related fields who are interested in global cooperation initiatives spawned by goals like those expressed in the United Nation's Sustainable Development Goals. This book may also be of interest to public officials faced with a request or an opportunity to participate in multi-country cooperation initiatives involving public and private sector participants. Communities with common interests in addressing global challenges are aggregating around topics like global health, environmental sustainability, education and poverty reduction programs. These topics address challenges spanning national borders, therefore encouraging cooperation among nations and private sector actors.

This book examines the emergence of so-called global partnerships sometimes referred to in literature as public-private partnerships or PPPs. ${ }^{1}$ These partnerships are intended to address global and regional challenges, by synthesizing resources, ideas, technical expertise and good will. Whether a challenge is in fact global, or simply common to more than one nation, is only a matter of scale. The past 20 years have witnessed a rise in cooperation through mechanisms called PPPs but which seek an institutional form through which to organize and operate.

However, international cooperation projects involving actors from both public and private spheres, are sometimes constrained by the available forms of national and international organizations used in the modern world as vehicles for organizing and directing human activity. As a result, those involved in global or regional partnerships are faced with the daunting task of choosing a form of institution allowing them to aggregate expertise and money in order to operate across many countries. During this evolutionary time of increased multi-national cooperation with private sector actors, a review of the available

$1 \quad$ See generally, Pauline Rose, Achieving Education for All Through PublicPrivate Partnerships?, Development in Practice, Vol. 20, No. 4/5 (June 2010); Vickram Cottage and Clean Mandri-Perrott, Public-Private Partnerships in Europe and Central Asia: Designing Crisis-Resilient Strategies and Bankable Projects (World Bank Publications, 2011). 
institutional forms may both illustrate the challenges faced by those thinking big and may help inform new types of institutional arrangements to harness cooperative resources.

\subsection{ADDRESSING POVERTY AND DEVELOPMENT CHALLENGES}

In 2008, the World Bank estimated that more than 1.3 billion people were living on US $\$ 1.25^{2}$ or less per day. ${ }^{3}$ By 2015 , that number was revised downward to around 738 million people living in extreme poverty; ${ }^{4}$ measured by chronic shortages of food, safe drinking water, basic healthcare, sanitation, education, shelter and clothing, which continue to be endemic across three principal regions: East Asia, South Asia, and sub-Saharan Africa. ${ }^{5}$ Across these geographic areas, in 2005 as many as 20000 people perished daily from lack of nutrition, clean water and healthcare. ${ }^{6}$ Today, the statistics remain grim regarding child mortality and the connection between poverty and premature death. ${ }^{7}$ It is commonly accepted that many countries struggle to overcome social and economic difficulties in an age of increasing global interdependence.

Many lower income countries are former colonies whose poverty intensified after gaining independence. Former colonies, including small islands and landlocked countries, struggle to raise standards of living and join the global economic order. ${ }^{8}$ During the past half-century, the wealth of so-called

2 In October 2015, the World Bank updated the so-called "International Poverty Line" upward to $\$ 1.90$ to adjust for inflation (accessed 20 November 2019 at http:// www.worldbank.org/en/topic/poverty/brief/global-poverty-line-faq).

3 See, World Bank website: (accessed 15 November 2019 at http://iresearch .worldbank.org/PovcalNet/index.htm?1).

4 See, World Bank website (accessed 30 November 2019 at https://www.worldbank .org/en/topic/poverty/overview).

5 Jeffrey D. Sachs, The End of Poverty: Economic Possibilities for Our Time (The Penguin Press, 2005) p. 3.

$6 \quad I d .$, p. 1.

7 See, UN News website: Poverty and Early Deaths Await Millions of World's Most Disadvantaged Children - UNICEF (accessed 30 November 2019 at https://news .un.org/en/story/2016/06/533242-poverty-and-early-deaths-await-millions-worlds -most-disadvantaged-children).

8 See, T.N. Srinivasan, Trade, Growth and Poverty Reduction: Least-Developed Countries, Landlocked Developing Countries and Small States in the Global Economic System (Commonwealth Secretariat, 2009) (the least developed countries contain nearly a billion citizens trapped in conflict zones, natural resource-deprived areas, land-locked areas and regions with poor governance structures) p. 37; see also M. Shamsul Haque, The Fate of Sustainable Development under Neo-Liberal Regimes in Developing Countries in International Political 
developed countries has grown substantially. At the same time, poverty has worsened in some countries, which are seemingly caught in a cycle of deprivation. Exponentially increasing populations, decreasing natural resources and changes to climate and geography only intensify the challenges facing these countries. $^{9}$ In addition to population and natural resource challenges, developing countries often struggle to maintain predictable and stable governance and legal mechanisms for managing the affairs of the modern State. Those challenges include the provision of adequate public services for citizens. Absent a stable political and legal system, and given weak physical infrastructure, countries labor to participate effectively in global commerce. Globalization arguably creates even greater inequality between so-called developed and developing countries. By any measure there are enormous differences in the average incomes of the richest and the poorest countries. ${ }^{10}$ Over the past few decades of global market integration, it has been asserted that inequality may be levelling off, and this is in part attributable to economic growth in China, India, Southeast Asia and parts of South America. ${ }^{11}$

While opinions differ about whether joining the global marketplace is an undisputed positive, many in the global development community fundamentally believe that poor countries must make improvements to physical and social infrastructure to overcome poverty. ${ }^{12}$ Principles enshrined in the UN Charter and other international instruments promote international cooperation

Science Review / Revue internationale de science politique, Vol. 20, No. 2, The Pursuit of Sustainable Development: Concepts, Policies and Arena (April 1999) pp. 197-218.

9 Dennis A. Ahlburg, Allen C. Kelley and Karen Oppenheim Mason, eds., The Impact of Population Growth on Well-Being in Developing Countries (Springer, 1996) (discussing effects of population growth on poverty) p. 6.

10 CIA Factbook website, Country Comparison: GDP - Per Capita (PPP) (accessed 19 July 2018 at https:/www.cia.gov/library/publications/the-world-factbook/rankorder/ 2004rank.html); see also Nancy Birdsall, The World Is Not Flat: Inequality and Injustice in Our Global Economy, Lecture Prepared for UNU World Institute for Development Economics Research (UNU-WIDER: Helsinki, Finland, 2006) p. 19.

11 Id.

12 C.K. Prahalad, The Fortune at the Bottom of the Pyramid: Eradicating Poverty Through Profits (Prentice Hall, 2010) (for analysis of commercial enterprise targeting the bottom of the pyramid) p 3; see also Carsten Greve, The Global Public Private Partnership Industry in International Handbook on PublicPrivate Partnerships, G.A. Hodge, C. Greve and A.E. Boardman, eds. (Edward Elgar Publishing, 2010) pp. 499-508. 
aimed at improving the well being of the global community and living conditions for citizens everywhere. ${ }^{13}$

Multilateral and bilateral development assistance programs attempt to alleviate poverty by providing finance to poor countries. Over the past 50 years, it is reported that more than US\$1 trillion in development assistance has been transferred from wealthy countries to African nations, under the view that "the rich should help the poor, and the form of this help should be aid."'14 Significant funding provided by multilateral development institutions like the World Bank has financed the construction of roads, dams, airports and other physical infrastructure. ${ }^{15}$ However, commonplace images of men and women guiding overburdened wagons, towed by overworked pack animals, travelling alongside new highway systems continue to remind us of unsolved human struggles. In wealthier nations, a sense of increasing moral imperative and responsibility has led to calls for a massive response to address persistent poverty. ${ }^{16}$

Poverty across the globe is not delimited by national boundaries. Many issues share common attributes whose impacts are experienced in multiple States. This is the case for health, nutritional, educational and human-rights concerns. These challenges rise above national boundaries and impact the poorest on a regional basis. ${ }^{17}$ This fact has spurred big ideas among philanthropic and development initiatives and some public and private actors contemplate the world as a single de-territorialized orb with common problems to be addressed through global cooperation. ${ }^{18}$

13 See, Declaration on Principles of International Law concerning Friendly Relations and Co-operation among States in accordance with the Charter of the United Nations, A/RES/25/2625.

14 Dambisa Moyo, Dead Aid: Why Aid Is Not Working and How There Is a Better Way for Africa (Allen Lane, 2009) p. 1.

15 See, World Bank, Transformation Through Infrastructure, World Bank Group Infrastructure Strategy Group, 2012-2015 (World Bank, 2012).

16 Richard W. Miller, Globalizing Justice: The Ethics of Poverty and Power (Oxford University Press, 2010) p. 217; see also, Poverty Reduction: What Role for the State in Today's Globalized Economy?, Francis Wilson, Nazneen Kanji and Einar Braathen, eds. (Zed Books, 2001); and see generally, World BANK, Poverty Reduction and Growth: Virtuous and Vicious Circles, Guillermo Perry, ed. (World Bank Publications, 2006).

17 David Gordon, Child Poverty in the Developing World (The Policy Press, 2003) (overview of root causes of poverty) pp. 26-28.

18 Lael Brainard and Derek H. Chollet, Global Development 2.0: Can Philanthropists, the Public, and the Poor Make Poverty History? (Brookings Institution Press, 2008) (regarding increases in philanthropic funding) pp. 9-12. 


\subsection{UNITED NATIONS MILLENNIUM DEVELOPMENT GOALS, GLOBAL COMPACT AND AGENDA 21}

The current environment for overseas development program assistance finds its modern roots partially in post-World War II reconstruction. ${ }^{19}$ Bretton Woods Institutions and the Organisation for Economic Co-operation and Development (OECD) were founded to aggregate funding and coordinate development activities. The emergence of overseas development assistance (ODA) as a primary funder of international development programs during the last half-century combined with Marshall Plan funding to re-build post-World War II Europe. ${ }^{20}$

The premise was straightforward: development in poor countries could be facilitated by the introduction of capital and expertise, arranged through Bretton Woods and similar institutions. ${ }^{21}$ Today, those institutions include the 20 development banks, including the World Bank Group and more recently the Asian Infrastructure Investment Bank, more than 40 bilateral agencies, the United Nations and increasingly non-profit organizations.

The premises underpinning development funding have evolved over time, starting with ideas in the late 1940s that favored big capital injections to help facilitate self-sustaining economic improvement. The focus was and remains on big infrastructure projects underpinned by theories that encourage import substitution, industrialization and transportation to spur a "sequence of stages that would lead to a take-off into self-sustained growth." 22

Over time, additional principles have been incorporated into development theory, including concepts focused on development planning, capacity building and sustainable environmental principles, all of which have become part of the development discourse reflecting ground level realities. ${ }^{23}$ From a Western or Northern perspective the solution is now framed as a necessary collective

19 See, Edward S. Mason and Robert E. Asher, The World Bank Since Bretton Woods: the Origins, Policies, Operations and Impact of The International Bank for Reconstruction and Development (Brookings Institution Press, 1973).

${ }^{20}$ Francisco Sagasti, Official Development Assistance: Background, Context, Issues and Prospects, paper on G-20 ODA finance initiatives (October 2005) pp. 1-2 (accessed 10 March 2020 at https://www.researchgate.net/publication/258221158_The Evolution_of_Official_Development_Assistance).

${ }^{21}$ OECD website: About/History (the OECD was established in 1947 to help conduct the Marshall Plan for reconstruction and today includes 40 countries accounting for " $80 \%$ of world trade and investment") (accessed 19 November 2019 at http:// www.oecd.org/about/history).

22 Sagasti, Official Development Assistance, supra at note 20, p. 1.

23 Id. at p. 2. 
responsibility of governments, poor and rich, working together to improve the human condition. ${ }^{24}$

The World Bank and other development funding partners now acknowledge that poverty reduction strategies cannot remain focused solely on physical infrastructure projects but must shift "towards a more sustainable development trajectory ... and a balanced consideration of social, environmental and economic goals in public and private decision-making." 25 The current wave in development strategy encourages coordination across sectors to deal with increasingly complex and interconnected issues. ${ }^{26}$ In addition to building capacity and transferring knowledge, expertise and money, development theory now also focuses on remedying market failures that are thought to create or sustain cycles of poverty in developing countries. ${ }^{27}$

Thus, the international development community is engaged in a variety of programs aimed at reducing poverty. ${ }^{28}$ Addressing poverty and its many causes has become a key policy interest and has galvanized coordinated activity around the world, increasingly focusing on public-private initiatives. ${ }^{29}$ That activity has been spurred on by time-limited objectives including the United

24 See, Jacques Fomerand, The Politics of Norm Setting at the United Nations: The Case of Sustainable Human Development in, Rethinking International Organizations: Pathology and Promise, Yves Beigbeder and Dennis Dijkzeul, eds. (Berghahn Books, 2003) (citing the UNDP Human Development Strategy, Report 1993: "development is broad investment in human capacities including education, health and other skills to allow people to work productively and more creatively ..."), p. 78.

25 World Bank, Transformation Through Infrastructure, supra at note 15, p. 7.

26 Id.

27 United Nations, Human Development Report 2011, Sustainability and Equity: A Better Future for All (United Nations Development Programme, 2011) (noting "market-making PPPs are a key institutional innovation ... beyond traditional service delivery and infrastructure to bring together the potentially diverging interests of a wide range of stakeholders and blend various sources of finance") p. 2.

28 See, We Can End Poverty, Millennium Development Goals and Beyond 2015 (accessed 10 March 2020, at http://www.un.org/millenniumgoals/); see also, Balakrishnan Rajagopal, International law from Below: Development, Social Movements and Third World Resistance (Cambridge University Press, 2011); see also Celine Tan, The New Disciplinary Framework: Conditionality, New Aid Architecture and Global Economic Governance in InTERnATIONAL ECONOMIC Law, Globalization and Developing Countries, Julio Faundez and Celine Tan, eds. (Edward Elgar Publishing, 2010).

${ }_{29}$ See generally, Pauline Rose, Achieving Education for All through PublicPrivate Partnerships?, Development in Practice, Vol. 20, No. 4/5, (June 2010); see also, Vickram Cottage and Cledan Mandri-Perrott, Public-Private Partnerships in Europe and Central Asia: Designing Crisis-Resilient Strategies and Bankable Projects (World Bank Publications, 2011). 
Nation's Millennium Development Goals (MDGs). ${ }^{30}$ That activity is often initiated by shared interests in promoting development objectives held jointly by States and private actors. ${ }^{31}$

The MDGs and now the United Nation's Sustainable Development Goals (SDGs) are examples of initiatives that spawn multilateral cooperation between the State and private actors. Those goals fueled an interest in social action by articulating global objectives for addressing poverty. They are an example of a broad development framework with specified objectives. ${ }^{32}$ The MDGs were rooted in G-7/8 proclamations and UN resolutions that focus on eradicating extreme poverty and inequity facing developing countries. They comprised eight goals to be accomplished by 2015 through concerted international cooperation derived from the Millennium Declaration adopted by 189 nations - and signed by 147 heads of State and governments. ${ }^{33}$

The MDGs articulated eight goals regarding poverty and hunger, universal education, gender equality, child health, maternal health, combating HIV/ AIDS, environmental sustainability and promoting global partnership. Those objectives sought practical, measurable change for poor populations, targeting challenges faced across multiple countries. Annual progress reports detailed advances made toward the MDGs including progress in the prevention of armed conflict, the promotion of global health initiatives and the implementation of sustainable development strategies. ${ }^{34}$

These goals generated momentum for fundraising from both the private and public sectors to promote economic growth and development. The MDGs spawned a number of multi-actor development initiatives bringing public, private, intergovernmental and NGO organizations into collaborative relationships. ${ }^{35}$ Goal 8 specifically advocated "strong partnerships with the private

30 United Nations Millennium Development Goals website (accessed 21 November 2019 at http://www.un.org/millenniumgoals/).

31 United Nations Global Compact (accessed 2 December 2019 at http://www .unglobalcompact.org).

32 United Nations Millennium Development Goals: MDGs in Action (accessed 21 November 2019 at http://www.un.org/millenniumgoals/).

33 United Nations, The Millennium Development Goals Report 2010 (United Nations Department of Economic and Social Affairs, 2010).

34 Id., see also, Orin S. Levine, Thomas Cherian, Raj Shah and Amie Batson, Journal of Health, Population and Nutrition, Vol. 22, No. 3, Special Issue on a New Research Agenda for Introducing New Vaccines in Developing Countries: Translational Research (September 2004) (noting that the introduction of publicprivate partnership arrangements for the development and introduction of new vaccines has helped to improve the pricing and availability of vaccines to reduce childhood mortality) pp. 268-274.

35 See, United Nations website: Partnerships for Sustainable Development (accessed 30 January 2019 at http://sustainabledevelopment.un.org). 
sector and with civil society organizations in pursuit of development and poverty eradication." ${ }^{36}$

UN Resolution 56/76 encouraged global partnership activities noting that the objectives established in the United Nations Millennium Declaration, should facilitate collaboration in support of the MDGs. ${ }^{37}$ The Resolution stated that activities undertaken to "meet the challenges of globalization could benefit from enhanced cooperation between the United Nations and all relevant partners, in particular the private sector, in order to ensure that globalization becomes a positive force." 38

However, the legal bases for partnerships were not described in UN MDG literature. The only hint at a legal framework to help implement MDGs partnerships was articulated by Jeffrey Sachs who defined them as transactions whereby the public sector takes the "lead in arranging financing and in the regulatory structure ... for a project or program, and the private sector provides the services on a contractual basis." ${ }^{39}$ Professor Sachs is describing a contractual relationship where the public is the purchaser and the private sector is a service provider. That type of contractual arrangement has historically been used to finance and build physical infrastructure. His definition does not contemplate the complex governance and operational facilities required to mobilize and coordinate the efforts of public and private actors in a unified institutional vehicle. This begs a question: what are the best institutional forms suited to leverage resources and galvanize actors through coordinated governance and operational structures?

Given the financial imbalances between rich and poor countries, the MDG Progress Report 2011 called for even greater funding by private partners, including philanthropic organizations, to finance MDG projects. ${ }^{40}$ The MDG Progress Report for 2012 notes that "[w]orking together, Governments, the United Nations family, the private sector and civil society have succeeded in saving many lives and improving conditions for many more." ${ }^{41}$ As globally interconnected economies, population growth and migration increase pressure

36 United Nations, General Assembly Resolution Towards Global Partnerships, 58/129, 19 December 2003. MDG 8 provided targets focused on addressing the special needs of least developed countries, landlocked countries and small island developing States in partnership with private sector actors.

37 Id

38 Id. (naming particular multi-stakeholder initiatives like Gavi as examples).

39 Jeffrey Sachs et al., Investing in Development, A Practical Plan to Achieving the Millennium Development Goals (Earthscan UNDP, 2005) p. 50.

40 See generally, Millennium Development Goals Report, 2011 (accessed 10 March 2020 at https://www.un.org/millenniumgoals/MDG2011_PRa_EN.pdf).

41 United Nations, United Nations Millennium Development Gölds Report, 2012 (United Nations, June 2012) p. 4. 
on natural resources, so will the necessity for global and regional initiatives aimed at coordinated action.

Prior to adoption of the SDGs, other initiatives arose to stimulate cooperation. The Global Compact is an example of a goals framework that encourages public-private development cooperation. ${ }^{42}$ Secretary-General Kofi Annan announced at the World Economic Forum in January 1999 that a new "Global Compact" of shared values and principles should be initiated as a framework to encourage best practices. The compact was founded on so-called universal values to encourage businesses to voluntarily adhere to specific principles in support of international development programs.$^{43}$ In July 1999, the Secretary-General issued the UN's guidelines for cooperation with the business community ${ }^{44}$ The Global Compact provided support for the usefulness of public-private initiatives and over next five years, the UN General Assembly issued several resolutions promoting partnerships; including a series of resolutions encouraging greater interaction with the private sector ${ }^{45}$ Resolution 58/129 noted the Global Compact Initiative and welcomed the "establishment of a multitude of partnerships at the field level, entered into by various United Nations agencies, non-State partners and Member States." ${ }^{46}$

The Global Compact articulates two main objectives: socialize 10 principles for global business activities and catalyze coordinated actions. ${ }^{47}$ The framework for partnering with the private sector includes leveraging the UN's "moral authority and convening power, with the private sector's solution-finding strengths, and the expertise and capacities of a range of key stakeholders." ${ }^{" 48}$ This, it was thought, would bring private sector participation to help manage risks and provide expertise for global development solutions.

42 See generally, United Nations Global Compact website (accessed 20 November 2019 at http://www.unglobalcompact.org).

43 Benedicte Bull and Desmond McNeill, Development Issues in Global Governance; Public-Private Partnerships and Market Multilateralism (Routledge, 2007) p. 6.

44 Id.

45 United Nations General Assembly Resolution 56/76; Towards Global Partnerships; 11 December 2001. The Resolution noted that the principles governing partnership arrangements should be founded on United Nations purposes and principles pursuant to the Charter but "without imposing undue rigidity in partnership agreements"); see also related resolutions: 2011: (A/RES/66/223); 2009: (A/RES/64/223); 2007: (A/RES/62/211); 2005: (A/RES/60/215); 2003:(A/RES/58/129); 2001: (A/ $\mathrm{RES} / 56 / 76)$.

46 United Nations, General Assembly Resolution Towards Global Partnerships, 58/129, 19 December 2003.

47 UN General Assembly Resolution 56/76; Towards Global Partnerships; 11 December 2001.

48 Id. 
The objectives of the Global Compact include encouraging commercial enterprises to align operations and strategies with 10 universally accepted principles in the areas of human rights, labor, environment and anti-corruption. ${ }^{49}$ That compact aims to strengthen markets and help ensure that technology and financing are made available while realizing social benefits. The goals include "building markets, combating corruption, safeguarding the environment and ensuring social inclusion" to support partnerships between business, government, NGOs, labor and UN agencies. ${ }^{50}$

The Global Compact is reported to be the "largest corporate citizenship initiative" in the world.$^{51}$ It includes corporate participants and other stakeholders from more than 130 countries. ${ }^{52}$ Although resulting in greater interaction between the private sector and international organizations, this is not without controversy. Scholars debate the appropriateness of bringing big business into cozier relations with the UN. ${ }^{53}$ That idea has also been strongly criticized by the NGO community. ${ }^{54}$

Another pre-SDG initiative was branded Agenda 21 and proposed as a comprehensive plan for global, national and local organizations to coordinate with the UN and States to address environmental impacts. ${ }^{55}$ Agenda 21 was adopted by more than 178 States at the United Nations Conference on Environment and Development in 1992. ${ }^{56}$

The objectives of Agenda 21 were reaffirmed at the World Summit on Sustainable Development held in Johannesburg, South Africa in 2002,

49 See, UN Partnership Compact Principles (which are grouped around Human Rights, Labour Standards, Environment and Anti-Corruption), Global Compact website (accessed 20 November 2019 at http://www.unglobalcompact.org); see also, Paige Willan and Kasey Lindsey, Geo. J. InT'L L. VoL. 39 (Georgetown Journal of International Law Summer, 2008) p. 573.

50 UNDP, Global Compact Report (accessed 10 March 2020 at https://www .unglobalcompact.org/participation/report).

51 Andreas Rasche and George Kell, eds., The United Nations Global Compact: Achievements, Trends and Challenges (Cambridge University Press, 2010) p. xxix.

$52 \quad I d$.

53 See, Jean-Philippe Thérien and Vincent Pouliot, The Global Compact: Shifting the Politics of International Development?, Global Governance, Vol. 12, No. 1 (January-March 2006) (noting the deep debate about whether the Global Compact provides appropriate benefits to developing countries given the profit motives of the private sector which may exist under a "thin veneer of social conscience") pp. 57, 67.

54 John Ruggie, Remarks on the Global Compact to the NGO Community (accessed 10 March 2020 at https://www.business-humanrights.org/sites/default/files/reports-and -materials/UN-Global-Compact.htm).

55 See, United Nations, Agenda 21: Earth Summit - The United Nations Programme of Action from Rio (United Nations, ISBN 13: 9789211005097, 1993).

56 Id. 
which reportedly launched more than 200 new PPPs. ${ }^{57}$ Summit participants considered the appropriate role of business in international development. Summit attendees focused on creating soft partnering relationships rather than concentrating on the establishment of treaties and organizations based on international law. ${ }^{58}$

The Summit drove the sustainable development agenda toward cross-sectoral cooperation, encouraging active partnerships. ${ }^{59}$ The event featured thousands of participants representing heads of State, national delegates, leaders from the private sector, including non-governmental organizations and businesses. ${ }^{60}$ Some participants advocated for soft organization models rather than State treaty models. ${ }^{61}$ The Summit laid the groundwork for broad collaboration across all sectors and types of actors, including such diverse groups as farmers, youth groups and labor unions. ${ }^{62}$ This trend appears to be consistent with the growing tendency "for non-state actors to be involved in creating and operating international environmental partnerships." ${ }^{63}$ Agenda 21 was intended to facilitate collaboration through worldwide consensus building.

The UN and other intergovernmental organizations have added strong voices in support of the partnership movement. A key feature of such messages was the call for non-State actors, NGOs and private sector corporations, to join global development initiatives. A series of United Nations General Assembly Resolutions issued under the title "Towards global partnerships" illustrate UN support for partnering arrangements. ${ }^{64}$ In those Resolutions, the UN expressed a keen interest to work across sectors to address development goals. ${ }^{65}$

57 Bull and McNeill, Development Issues in Global Governance, supra at note 43, p. 10.

58 Thomas G. Weiss, What's Wrong with the United Nations and How to Fix It (Polity Press, 2012) p. 170.

59 See, CSD-11 Decision on Partnerships: in Sections 21 and 22 (partnerships are voluntary multi-stakeholder initiatives that contribute to the implementation of inter-governmental commitments in Agenda 21).

60 See, Johannesburg Summit, Background (accessed 10 March 2020 at https:// digitallibrary.un.org/record/478154? $\ln =\mathrm{en})$.

${ }^{61}$ Weiss, What's Wrong With the United Nations, supra at note 58, p. 70.

62 United Nations, Report of the World Summit on Sustainable Development, (United Nations, 2002).

63 Jeffrey McGee and Taplin Roslyn, The Asia-Pacific Partnership and the United States' International Climate Change Policy, Colorado Journal of International Environmental Law and Policy, p. 179.

64 United Nations Resolutions: (A/RES/66/223); 2009: (A/RES/64/223); 2007: (A/ RES/62/211); 2005: (A/RES/60/215); 2003: (A/RES/58/129); 2001: (A/RES/56/76).

65 Benedicte Bull, Public-Private Partnerships: The United Nations Experience, in International Handbook on Public-Private Partnerships, G.A. Hodge, C. Greve and A.E. Boardman, eds. (Edward Elgar Publishing, 2010) (noting the UN dual role 
Secretary-General Ban Ki-moon expressed the UN position as follows, noting that the "United Nations can only do its job properly with partners. We will need to forge even closer ties with civil society groups, foundations, academic institutions, the media, labour unions, and the private sector. Each has unique contributions to make." ${ }^{66}$

Looking past the MDG deadline of 2015, the UN appointed a panel to review the MDGs which concluded that there is "an opportunity in the post-2015 agenda to include new players in partnerships at all levels, to introduce new ways of working across an agenda that goes beyond aid, and to introduce a new spirit of multilateralism and international cooperation." High-Level Panel Report declares that "goal-or sector-specific global partnerships should be a central part of the new development agenda ... involving business, civil society, philanthropic organisations, international organisations and governments." ${ }^{68}$ This conclusion about the value of public-private cooperation demonstrates the movement to be more than a passing fad.

\subsection{INTRODUCTION TO THE SUSTAINABLE DEVELOPMENT GOALS}

In 2015, the General Assembly commissioned a Millennium Development Goals Report (MDG Report) to track progress toward the goals established 15 years prior. In his foreword to the MDG Report, former Secretary-General Ban $\mathrm{Ki}$-moon praised the MDGs as the "most successful anti-poverty movement in history." ${ }^{69}$ Despite measurable achievements, the report noted that progress was uneven and the global community failed to meet all the goals. The United Nations then launched the 2030 Agenda for Sustainable Development, which

of encouraging capitalist interventions for development purposes while attempting to protect the most vulnerable citizens) pp. 480-481.

66 Ban Ki-moon, UN Secretary-General, Address to the UNA-USA Business Council for the UN, New York, 10 January 2007 (accessed 10 March 2020 at https:// www.un.org/sg/en/content/sg/speeches/2007-01-10/address-una-usa-business-council -united-nations-and-association).

67 United Nations, A New Global Partnership: Eradicate Poverty and Transform Economies through Sustainable Development: The Report of the High-Level Panel of Eminent Persons on the Post-2015 Development Agenda (United Nations, 2013) (accessed 30 November 2019 at http://www.post2015hlp.org/wp-content/uploads/ 2013/05/UN-Report.pdf) p. 21 (hereafter "High-Level Panel Report").

$68 \quad I d .$, p. 23.

69 The Millennium Development Goals Report 2015 (MDG Report) (accessed 30 November 2019 at https://www.un.org/millenniumgoals/2015_MDG_Report/pdf/ MDG\%202015\%20rev\%20(July\%201).pdf). 
calls on UN Member States to achieve 17 goals by $2030 .^{70}$ The SDGs frame objectives that require globally coordinated efforts. ${ }^{71}$ Adopted by the UN after consultation with public and private institutions and individuals, the SDGs fundamentally aim to reduce poverty, to improve the lives of citizens and to help ensure sustainable management of natural resources. ${ }^{72}$

The MDG Report highlights the key distinctions between the approach taken under the MDGs and that proposed for the SDGs. The SDGs encourage cross-sectoral and cross-institutional collaboration to accelerate development progress while expanding global commitments in poor and wealthy countries alike. The MDGs represented a major step in global progress that fundamentally altered the world, particularly in comparison to the world at the time of adoption. While many of the MDGs were met to one degree or another, progress on some goals lagged behind, "especially for the education and health-related MDGs." 73 City dwellers reportedly experienced more development progress compared to rural populations. The MDG Report flags uneven investment, inefficient resource allocation, weak intergovernmental engagement and other endemic issues as bottlenecks. It also articulated lessons learned which informed the development goals and targets of the SDGs. The MDG Report promotes the idea that UN organizations should embrace the One UN approach which is "a universal, integrated and human rights-based agenda for sustainable development." 74 This requires a symbiotic relationship between countries at every level, including monitoring, progress updates and sharing good practices. Development goals in both the MDGs and SDGs are connected, but a unified approach was reported to be necessary to reverse the impact of bottlenecking. ${ }^{75}$

\footnotetext{
70 United Nations website (accessed 28 February 2020 at https:// sustainabledevelopment.un.org/sdgs).

71 The Sustainable Development Goals are the next iteration of development objectives initially framed by the United Nations Millennium Development Goals.

72 See, We Can End Poverty, Millennium Development Goals and Beyond 2015 (accessed 28 March 2020, at http://www.un.org/millenniumgoals/); see also, Balakrishnan Rajagopal, International Law from Below: Development, Social Movements and Third World Resistance (Cambridge University Press, 2011); see also Celine Tan, The New Disciplinary Framework: Conditionality, New Aid Architecture and Global Economic Governance in InTERnATIONAL ECONOMic Law, Globalization and Developing Countries, Julio Faundez and Celine Tan, eds. (Edward Elgar Publishing, 2010).

73 See MDG Report supra at note 69.

74 See UNDP-World Bank Report, Transitioning from the MDGs to the SDGs (accessed 12 September 2019 at https://www.undp.org/content/dam/undp/library/ SDGs/English/Transitioning\%20from\%20the\%20MDGs\%20to\%20the\%20SDGs .pdf).

${ }_{75} I d$.
} 


\subsection{SDG 17 - PARTNERSHIP}

SDG 17 sets its sights on global partnership and cooperation, aimed at enhancing "North-South and South-South cooperation" to facilitate fair and equitable trading systems to promote sustainable growth and development of developed and underdeveloped countries alike. ${ }^{76}$ The types of partnerships registered in the UN SDG roster include participants from States, civil societies, local authorities, the private sector, scientific and technological communities and academia. ${ }^{77}$ Partnerships are grouped generally as voluntary arrangements or as multi-stakeholder partnerships with financial commitments. For SDG 17, a key question arises: Will the SDGs actually be more successful in fostering partnerships than the MDGs?

The SDGs were a product of a larger-scale bargaining process that included both developing and developed countries in consultation. With a range of stakeholders representing those same consultative countries and the private sector, the prospect of successful partnering became informed by the lessons learned from the MDG era. If SDG 17 indicators are to be obtained, significant resource mobilization will be required by developed and developing countries and better implementation of existing cooperation to promote long-term sustainability. ${ }^{78}$ The SDG Fund was introduced to help accomplish this goal. ${ }^{79}$ The Fund attempted to streamline cooperation and it relied on the concept of matching funds provided by partners to increase finance. Although the Fund is operationally closed, its functions are now transferred to the Joint SDG Fund to improve finance for development programs. ${ }^{80}$

While the purpose of the SDGs is to encourage global partnership and cooperation, there is no guidance in UN SDG literature about the forms of institutional structures that partnering requires. The question remains about whether a form or forms of legal organization are required to facilitate collaboration to align governance and operational functions within a responsible body? This is in contrast to attempting cooperation through multiple cross-referencing memoranda and agreements to coordinate disparate actors. Without a workable

\footnotetext{
76 Id

77 See, Partnerships for SDGs - 2016 special report (accessed on 10 March 2020 at https://sustainabledevelopment.un.org/sdinaction/2016report).

78 See, United Nations SDG website (accessed 30 November 2019 https://www .localizingthesdgs.org/library/251/From-MDGs-to-SDGs-What-are-the-Sustainable -Development-Goals.pdf).

79 See, UN SDG Fund website (accessed 20 November 2019 at https://www .sdgfund.org).

80 See, Joint SDG Fund website (accessed 10 March 2020 at https://jointsdgfund .org/who-we-are).
} 
framework, SDG 17 does not address key legal and governance challenges that may be overcome through formalized institutional cooperation.

\section{$1.5 \quad$ SEGUE}

The topic of this book is now framed. Politicians, philanthropists, NGOs and international organizations strive to address poverty and other challenges articulated in the context of the SDGs and similar objectives. Poverty reduction and addressing global development challenges are key public policy concerns that can ignite coordinated financial and technical activity around the world. Given the complexity and geographic range, the most pressing challenges - advancement toward the SDGs - may be increasingly achieved through public-private cooperation.

In this book, the term "State(s)" is used to reference sovereign countries and the term "non-State" refers to private sector actors, for profit, non-profit and private individuals.

When States and non-State actors engage in large-scale development cooperation, public international and national legal systems interact. One of the challenges facing institutional initiatives aimed at the SDGs is finding a legitimate form of entity through which to operate. Public-private cooperation requires legal and regulatory compliance at different levels, from international public law to national systems, sometimes referred to as municipal or domestic law. The topic of institutional design may help to inform how the various actors may cooperate given the many legal systems involved. Global partnership ideas challenge us with questions about institutional design, in a world where such partnerships sometimes gain momentum outside traditional legal processes and frameworks. ${ }^{81}$ Large-scale public-private cooperation creates practical challenges for initiatives operating outside or partially within several legal frameworks.

Practical challenges are raised, since public-private cooperation has the potential to be a primary mechanism to support the SDGs. Where do publicprivate cooperation institutions fit within the realms of international and national law, and what legal rights and responsibilities attach?

This book aims to serve as a guide to help curious learners better understand the issues, benefits and challenges of public-private cooperation. The issues are largely the same regardless of scale. The author intends readers to acquire the requisite knowledge and tools to better contribute to and interact with complex public-private initiatives. At the center of the current discourse, is

81 Günther Teubner, Global Bukowina: Legal Pluralism in the World Society in Global Law without a State (Dartmouth/Aldershot 1997). 
the widely accepted premise that public-private collaboration between State and non-State actors is a legally valid and useful response to development challenges. ${ }^{82}$ The next chapter will review one historic thread of public-private cooperation, commencing 500 years ago, the impacts of which continue to be felt globally. This topic anticipates the rise of complex partnering arrangements and the strange and complicated forms they assume.

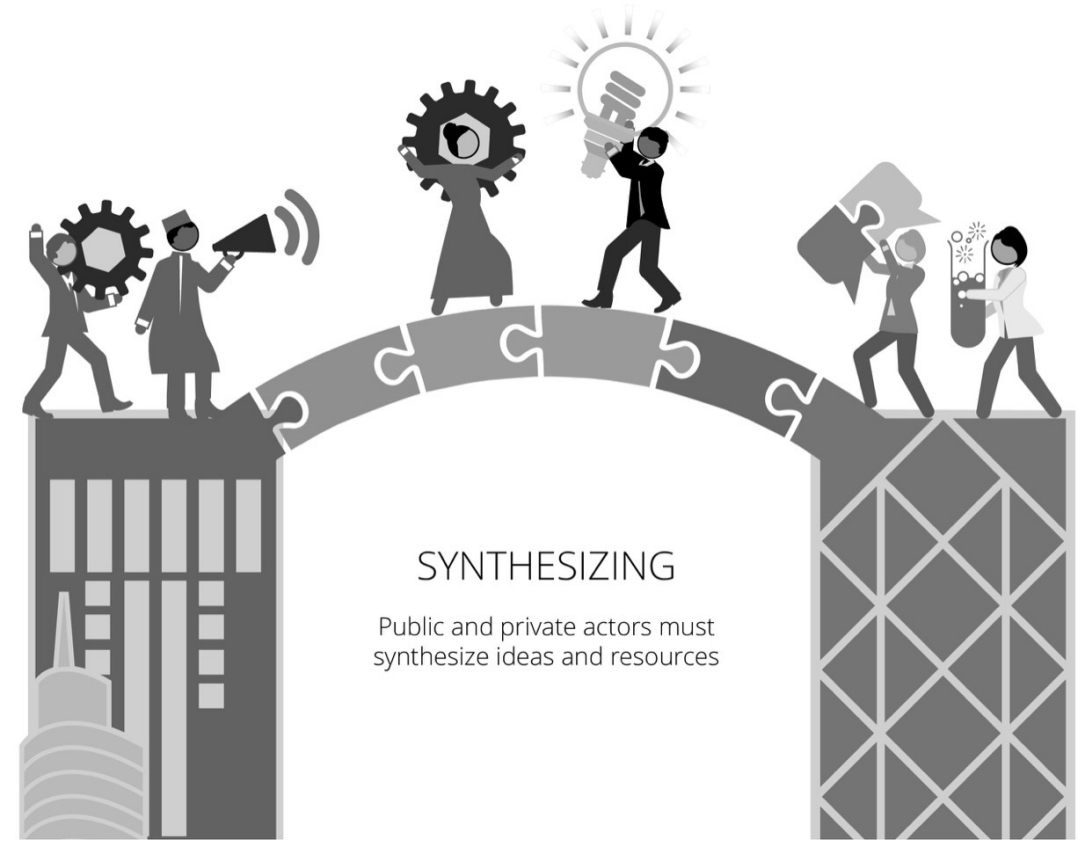

Figure 1.1 Synthesizing ideas and resources

82 See, Paul Collier, The Bottom Billion: Why the Poorest Countries Are Failing and What Can Be Done About It (Oxford University Press, 2007). 